\title{
Unpacking Decades of Multi-Scale Events and Environment-Based Development in the Senegalese Sahel: Lessons and Perspectives for the Future
}

\author{
Hugo Mazzero ${ }^{1}$, Arthur Perrotton ${ }^{2,3}{ }^{\circledR}$, Abdou Ka ${ }^{3,4}$ and Deborah Goffner ${ }^{3,5, *}$ \\ 1 UMR 5319 Passages (CNRS), Université Bordeaux Montaigne, Maison des Suds, 12 Espl. des Antilles, \\ 33600 Pessac, France; hugo.mazzero@u-bordeaux-montaigne.fr \\ 2 Centre de Coopération Internationale en Recherche Agronomique pour le Développement (CIRAD)—UPR \\ 105 Forêts et Sociétés, CEDEX 5, 34398 Montpellier, France; arthur.perrotton@cirad.fr \\ 3 Centre National de la Recherche Scientifique (CNRS) - IRL 3189 "Environnement, Santé, Sociétés", \\ 13015 Marseille, France/Université de Bamako, Mali/CNRST Burkina-Faso, Université Cheikh Anta Diop, \\ Dakar, Senegal; a.ka8@univ-zig.sn \\ 4 Université Assane Seck, B.P: 523, Ziguinchor 27000, Senegal \\ 5 Stockholm Resilience Center (SRC), Stockholm University, 10405 Stockholm, Sweden \\ * Correspondence: deborah.goffner@cnrs.fr; Tel.: +33-6-88-96-95-44
}

check for updates

Citation: Mazzero, H.; Perrotton, A.; Ka, A.; Goffner, D. Unpacking Decades of Multi-Scale Events and Environment-Based Development in the Senegalese Sahel: Lessons and Perspectives for the Future. Land 2021, 10, 755. https://doi.org/10.3390/ land10070755

Academic Editors: Tomasz Noszczyk and Abreham Berta Aneseyee

Received: 23 June 2021

Accepted: 14 July 2021

Published: 19 July 2021

Publisher's Note: MDPI stays neutral with regard to jurisdictional claims in published maps and institutional affiliations.

Copyright: (c) 2021 by the authors. Licensee MDPI, Basel, Switzerland. This article is an open access article distributed under the terms and conditions of the Creative Commons Attribution (CC BY) license (https:// creativecommons.org/licenses/by/ $4.0 /)$.

\begin{abstract}
A major challenge faced by human societies is to promote development that truly makes difference for people without jeopardizing their environment. This is particularly urgent in developing countries where, despite decades of development programs, local populations often live under poverty thresholds. With this study, we participate in the ongoing debate about the necessary global revision of development theory and practice in the rural Sahel. We retrace the development trajectories in the Ferlo, the northern silvopastoral zone of Senegal. We highlight how development has evolved from the 1940s to the present, from centralized development action programs focused on hydraulic infrastructure to current polycentric development with growing environmental concerns. We highlight multi-scale events that have influenced the successive development paradigms in the area. Focusing on the past thirty years, we analyzed twenty-five environment and natural resource management-oriented projects, describing the evolution of their objectives and actions over time and identifying recurring flaws: redundancy, lack of synergy, and questionable relevance to local needs We put forth that a more resilient thinking-based development paradigm is necessary to guide the growing number of environment-oriented development actions, including the African Great Green Wall, for which massive investments are ongoing throughout Ferlo and across the Sahel.
\end{abstract}

Keywords: Senegal; Ferlo; Green Wall; development; environment

\section{Introduction}

In 2014, the Doing Development Differently manifesto painted a rather negative picture of mainstream development when it stated that "too many development initiatives have limited impact ( . . ) because genuine development progress is complex [and] development initiatives fail to address this complexity, promoting irrelevant interventions" [1] Although roughly 1 billion people were lifted out of poverty worldwide between 1990 and 2015 [2], extreme poverty remains [3] and environmental concerns have never been greater despite sustainable development efforts, with a tendency towards increased biodiversity loss [4], desertification and related migration [5], and pollution-related disease [6]. Beyond criticism of sustainable development [7], many authors have raised issues underlying the rationales, agendas, and practices of development in general [8]. The success of development initiatives ultimately depends on understanding the complex and entwined dynamics involving, among others, coherent institutional and governance structures [3,9], holistic approaches of human and environment relationships [10], and accountability [11-13]. 
Since their independence, many Sahelian countries have invested massively in their own national development programs and projects, while nonetheless still remaining target countries of the international development agenda [14]. In this paper, we define a development project as a temporary organization with human, technical, or financial means to meet its own objectives over a given period of time, a development program being a set of projects with similar objectives [15]. This paper focuses on development trajectories in the Senegalese Sahel, located in the northern part of Senegal. Although this region has undergone significant transformations over the past decades in improved access to healthcare, education, and water as a result of development initiatives led by the Senegalese government and international organizations [16,17], ecological and social vulnerability still run rampant [18-20]. To address this vulnerability, current and future development actions must attempt to learn from past development initiatives.

As stated by Yevjevich and Starosolszky [21], conflicts between development needs and practice and environmental considerations are often inevitable. Despite the emergence of integrated approaches [22-24], typified by the Sustainable Development Goals (SDG 2016), critical environment-development issues remain. In rural Africa, where livelihoods depend primarily on natural resources, the literature provides numerous examples of controversial environment- or natural resources-based development initiatives and actions. Recurrent flaws include the failure to consider local governance and property rights with project activities result in serious social disturbances and tension (e.g., $[17,25]$ concerning water provisioning initiatives), or land tenure insecurity and other human rights-related issues (e.g., [26-29] around reforestation projects), and the lack of project reports (e.g., [30] concerning conservation projects) hinder the individual and institutional capabilities to learn and improve. This last flaw was one of the motivational factors to conduct this study.

Here, we specifically focused our analysis on natural resources management (NRM)related development initiatives, may they be through improving access to natural resources, rethinking natural resource governance, and/or establishing protected areas. This focus was also motivated by the fact that Senegal not only is currently investing heavily in their own large-scale NRM and restoration initiatives, but it also receives sizeable funding from the international development community. The most ambitious example is the Great Green Wall for the Sahara and Sahel Initiative (GGW) [31-33]. From the original idea of creating a wall of trees across the African continent, the vision of the GGW progressively evolved towards integrated landscape-scale interventions, resulting in a far greater complexity for NRM decision-making than originally imagined [34].

To inform current and future development initiatives, we first analyzed multi-scale historical events that have shaped development trajectories of the Senegalese Sahel. We then undertook a systematic analysis of the evolution of environment-oriented development initiatives over the past thirty years. Our hypotheses are formulated as follows: (i) environmental-based development is not prioritized in the Ferlo due to the marginalized position (spatially and socioeconomically) of the region; (ii) development projects are still carried out using a top-down approach, despite decentralization and an increasing emphasis on participatory approaches, mainly due to a lack of financial and political capacity; (iii) development projects lack synergy because there is no consultation framework through which all stakeholders can exchange and make their positions heard, and because there are no effective intermediaries operating between the different scales.

\section{Materials and Methods}

\subsection{Constitution of a Theoretical Corpus to Frame Environment-Based Development}

Development studies offer a vast corpus of literature. To frame environment-based development, we first constituted and compiled a list of key references. This initial literature review gathered references with different scales of analysis (global, Sahel, Senegal, and Ferlo), with particular attention paid to development studies in southern countries $[8,9,11-14,35-37]$ and sustainable development and/or environmental based development [10,38-45]. Given the study area, this review included literature on conservation issues $[4,26,46-48]$, desertification 
in the Sahel [5,49-56], actions of reforestation and environmental restoration [27,31-34,57-64], issues around livestock and development dynamics [19,65-67], water provisioning and boreholes [16,17,68], and grazing land management and Senegalese pastoral units [69-71].

Concerning analytical frameworks, the literature offers many single project evaluations analyzing their sustainability [72], their ability to reconcile biodiversity conservation with human development [41,73], or their impact in relation to public engagement [74]. There are also analyses centered not on a project but on a domain, such as fisheries [75] or energy [76]. We did not identify any systematic studies that analyzed large sets of development projects in a specific area over time. The originality of our approach is thus to propose an analysis of projects at the local level, while linking them to the global dynamics in which they are embedded.

\subsection{Construction of a Multi-Scale Timeline}

In order to situate environment-based development initiatives carried out in northern Senegal in a larger historical context, a timeline was constructed based on scientific publications, grey literature, and internet sources (newspaper articles, NGO databases). This also allowed for a better understanding of project impacts and significance of events at the local scale.

\subsection{Geographic Scope of the Projects}

In Senegal, development projects often operate within administrative boundaries, usually focusing on a particular region or district. All selected projects have been (or are currently) carried out in at least one of the following 4 districts: Linguère, Ranérou-Ferlo, Matam, and Kanel, all of which are located in the Sahelian zone (Figure 1). Linguère is located in the administrative region of Louga, whereas the other three districts are in the region of Matam. Together, the four districts are located in an area referred to as the Ferlo, a vast area in northern portion of Senegal that occupies roughly $30 \%$ of the country [67]. Its geographic and even cultural delimitation varies according to authors [77]. The Ferlo is a vast silvopastoral zone, inhabited in large majority by Fulani pastoralists, and characterized by its extreme aridity and predominance of shrubby savannah and steppe vegetation. With the exception of irrigated agriculture on the banks of the Senegal river, the main incomegenerating activity is extensive livestock herding [78]. The Ferlo is the social-ecological system [40] that has been the main focus of development initiatives in the region during the past decades.

\subsection{Identification of Environment-Oriented Development Projects}

In order to identify development projects, we proceeded in three steps. The first step was an exploration phase via search engines (e.g., Google, Google Scholar) using the following keywords in French and English: zone sylvopastorale, silvopastoral zone, Ferlo, projets de développement, development projects, Linguère, Ranérou-Ferlo, Matam. This allowed us to identify a first set of projects, which was subsequently enlarged via snowball sampling. The second consisted of data collection using mainly official documentation produced by the projects themselves (final or mid-term evaluation reports, but also projects websites when existing). Databases produced by the Senegalese government, NGO reports and websites, national news media, and scientific articles were also used to target development projects and to complement the official documentation (Table S1). The third and final step was the creation of a repertory and a database of 25 projects (numbered 1 to 25) operating between 1996-2019 in the domains of agriculture, pastoralism, and environment (Table S2). For each project, the database includes the following information: project title, acronym, starting and ending dates, geographic location, objectives, actions, funders, and budget. For clarity's sake, projects are referred to by project name and number (P1 to P25) throughout the text. 


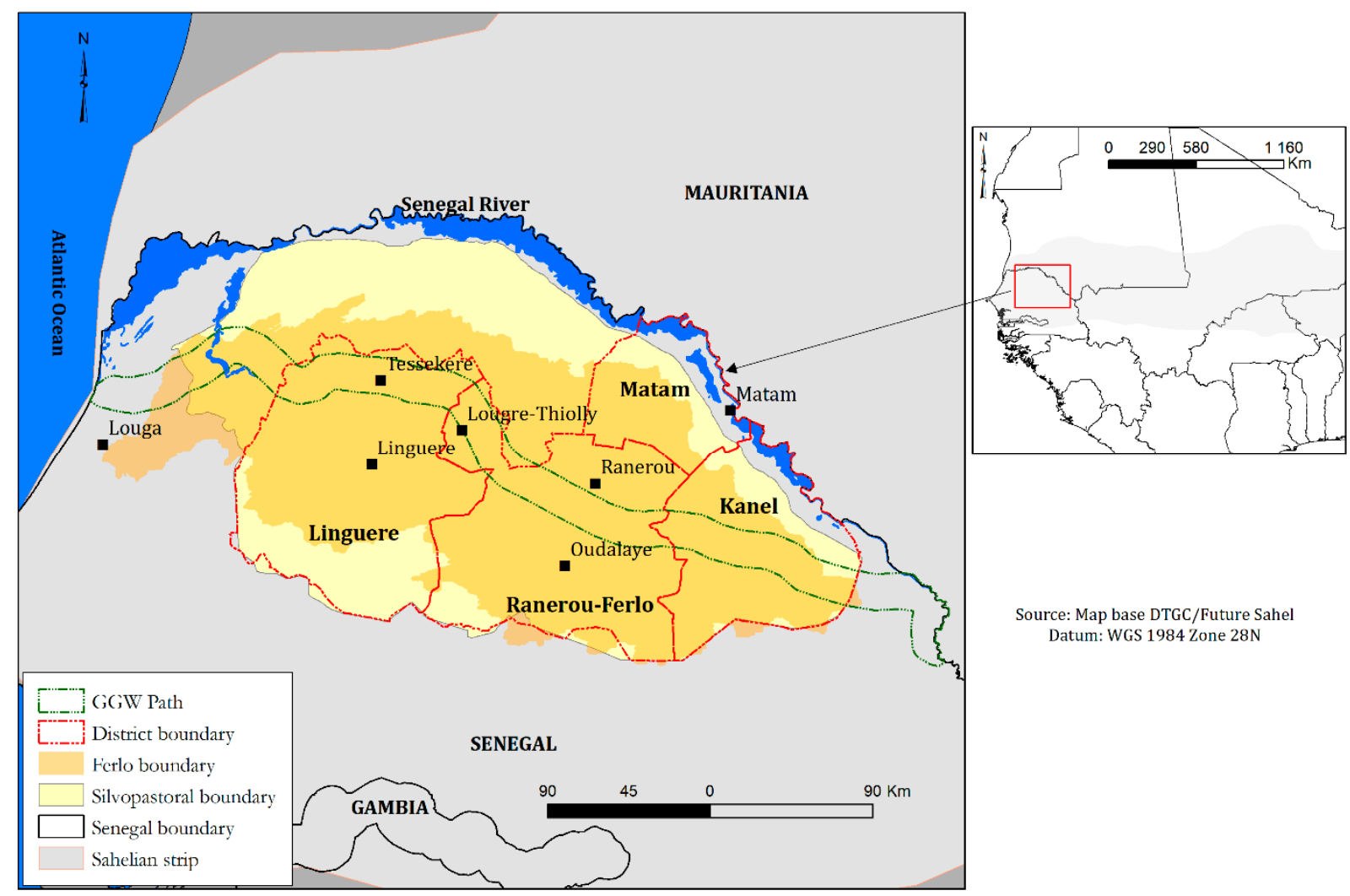

Figure 1. Map of the study area: the Senegalese Ferlo region. The map is centered on the northern part of Senegal, located in West Africa. It highlights the strong overlap among the silvopastoral zone (light yellow), the Ferlo (dark yellow area), and the four districts (outlined in red) where the environment-oriented development projects in this study were implemented: Linguère, Ranérou-Ferlo, Matam, and Kanel. Since it is the current, major environment-oriented project in the area, we also represented the Great Green Wall path (outlined in green).

\subsection{Project Characterization: Typologies}

One of the major challenges of the project analysis was the heterogeneity of terms and lexical fields used in the project documentation. To circumvent this difficulty and in order to compare projects, we created a typology according to project objectives and actions. Although all of the identified projects are related to the environment, the relationships are not always direct. We identified seven objective types, belonging to three distinct groups (Table 1). Two types of objectives are directly related to the environment itself: environmental protection and natural resource management. Two are related to production systems: agriculture and pastoralism. Three objectives are people-oriented: food security, capacity building, and fighting against poverty.

Table 1. Classification and description of project objective types. Seven objective types were identified. A definition for each objective type is provided. The definition of capacity building used herein is the one provided by the Development Assistance Committee of the Organization for Economic Co-operation and Development (OECD/DAC).

\begin{tabular}{ccc}
\hline & Objective Type & Description \\
\hline Environmental protection & $\begin{array}{c}\text { Protecting and conserving the } \\
\text { environment for its own sake and for } \\
\text { the benefits it brings to people }\end{array}$ \\
\cline { 2 - 3 } & Natural resource management & $\begin{array}{c}\text { Improving the sustainable use of } \\
\text { resources or ecosystem services, such } \\
\text { as water or trees }\end{array}$ \\
\hline
\end{tabular}


Table 1. Cont.

\begin{tabular}{|c|c|c|}
\hline & Objective Type & Description \\
\hline \multirow{2}{*}{ 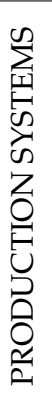 } & Agriculture & $\begin{array}{l}\text { Encouraging agricultural activities, } \\
\text { both food-producing and commercial, } \\
\text { by supporting farmers or facilitating } \\
\text { the conditions in which they carry out } \\
\text { their activities }\end{array}$ \\
\hline & Pastoralism & $\begin{array}{l}\text { Maintaining, promoting, and } \\
\text { improving the conditions for this } \\
\text { activity by modernizing or } \\
\text { intensifying it, but also preserving its } \\
\text { culture and traditions }\end{array}$ \\
\hline \multirow{3}{*}{ 点 } & Food security & $\begin{array}{l}\text { Ensuring food well-being for } \\
\text { populations. As a basic need for } \\
\text { development, it can be considered in } \\
\text { terms of access, quantity, quality, and } \\
\text { stability }\end{array}$ \\
\hline & Capacity building & $\begin{array}{l}\text { Increasing the ability of individuals, } \\
\text { organizations, and communities to } \\
\text { manage their daily lives successfully. } \\
\text { These are the processes by which } \\
\text { individuals, organizations, and the } \\
\text { community as a whole liberate, create, } \\
\text { strengthen, adapt, and preserve } \\
\text { capacity over time. Capacity can be } \\
\text { institutional or individual }\end{array}$ \\
\hline & Fight against poverty & $\begin{array}{l}\text { Improving the economic and social } \\
\text { conditions of populations through the } \\
\text { revival or creation of activities }\end{array}$ \\
\hline
\end{tabular}

As for actions, defined herein as the means to achieve the objectives, we identified eight action types (Table 2). Five are focused on creating or improving social structures and behavior: setting up social and economic structures, creation/improvement of pastoral units, training, studies, and awareness-raising. Two types of actions are related to the distribution of material goods: construction/renovation of infrastructures and donations. Finally, one action type is directly linked to the environment: environmental protection and restoration.

\subsection{In-Depth Studies of Three Selected Projects}

In order to assess the potential interactions and synergies amongst projects, three recent projects were selected for further analysis: the PADAER (P13), the PASA-LOUMAKAF (P14), and the PUDC (P20). These projects were selected because they (i) represent significant financial investment on behalf of the Senegalese government, (ii) operate in overlapping areas, (iii) have similar objectives and actions, and (iv) produced detailed reports. Based on a common interview guide, a total number of 32 semi-structured interviews with various stakeholders including national and local project coordinators and/or local natural resource (NR) managers (14), local authorities (10), project beneficiaries (6), and NGO members (2) were carried out in May 2017 and April 2018 (including 15 interviews in French, and with a translator: 15 in Puular and 2 in Wolof). Questions pertained to major themes including knowledge about development projects in the area (from a general point of view, or about a specific project and the way it was linked or not with other projects), local and historical context (especially linked with climatic issues, mainly droughts), pastoralism, and borehole issues. Responses were analyzed and compared in order to understand the degree of synergy amongst the three selected projects. This also allowed us to highlight the differences and the commonalities in the way development in the Ferlo is conceived. We 
first targeted local authorities, and then asked them for recommendations for other stakeholder interviews. Complementary data were also collected from informal conversations with local inhabitants. National project coordinators were interviewed in Dakar, whereas local project coordinators, authorities, and beneficiaries were interviewed locally, mainly in the district of Ranérou-Ferlo.

Table 2. Classification and description of project action types. Eight action types that development projects implement in the area were identified. The table provides a definition for each action type.

Action Type

Setting up social and economic structures

Creation/improvement of pastoral units

Training

\section{Description}

Any action aiming at bringing people together into organized structures.

These include the creation or strengthening of social and economic groups, such as cooperatives, economic groups, or associations

Any action that serves the purpose of developing or improving the network of pastoral units. These include the creation of new units as well as the reinforcement or monitoring of already existing ones

Any action involving general or technical knowledge and know-how transfer to local populations. These can be accompanied by donations of materials or infrastructure

Any action aiming at producing knowledge. These studies can be focused on the project's intervention area (e.g., baseline study, market survey) or on the project's achievements (e.g., monitoring, evaluation). These often involve the creation and implementation of information systems, surveys, or assessment protocols

Any action aiming at information sharing in order to have an impact on practices, behaviors, or mentalities of targeted populations. Topics

Awareness-raising include health and hygiene practices, bushfire management, etc. These actions often include meetings, along with the production of physical supports such as leaflets or signs (for example, fighting bushfires)

Any action consisting of constructing or renovating buildings,

Construction/renovation of infrastructure equipment, or amenities. These are most often the means to support or develop an economic activity

Actions consisting of directly donating products (materials or food) or funds (money)

Any action aiming at the preservation and restoration of the environment. These include establishing protected areas or reforestation plots

Environmental protection and restoration

\section{Results}

\subsection{A Multi-Scale Perspective of the Three Major Periods of Development in the Ferlo}

After being isolated from the outside world, the Ferlo has become increasingly impacted by events occurring at the national, continental, and global levels. Three major periods were identified, each of which have been triggered by a critical event or situation that significantly altered the ongoing development trajectory (Figure 2). These trigger events were political, climatic, or institutional in nature, and occurred at different scales. The three periods are sequentially described below with an emphasis on the cross-scale interactions that have participated in shaping local development trajectories in the Ferlo. 


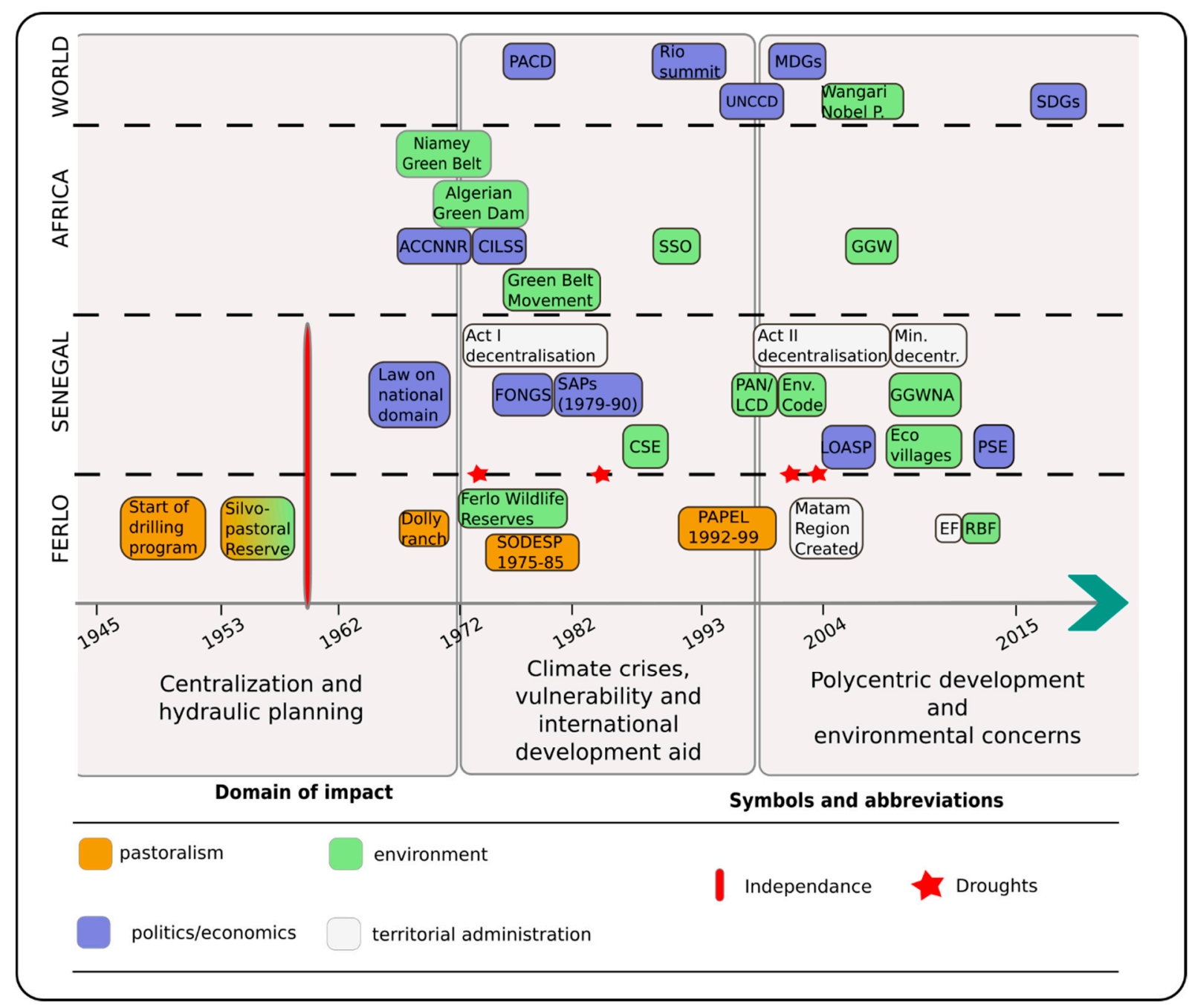

Figure 2. Multi-scale timeline defining three major periods of development in the Senegalese Ferlo region. The figure represents the three periods of development. The different events shaping the development in the Ferlo are represented according to their domain of interest and scale of influence. ACCNNR: African Convention on the Conservation of Nature and Natural Resources; CILSS: Permanent Interstate Committee for Drought Control in the Sahel; CSE: Centre de suivi écologique (ecological monitoring center); EF: “Entente” Ferlo; Env.Code: Environment Code; FONGS: Federation of NGOs of Senegal; GGW: Great Green Wall; GGWNA: Great Green Wall National Agency; LOASP: Agro-silvopastoral Orientation Act; MDGs: Millennium Development Goals; PACD: Plan of Action to Combat Desertification; PAN/LCD: National Action Program to Control Desertification; PAPEL: Livestock Support Project; PSE: Plan for an Emerging Senegal; RBF: Biosphere Reserve of Ferlo; SAPs: Structural Adjustment Programs; SDGs: Sustainable Development Goals; SODESP: Society for the Development of Livestock in the Silvopastoral zone; SSO: Sahara and Sahel Observatory; UNCCD: United Nations Convention to Combat Desertification.

\subsubsection{Centralized Development Focused on Hydraulic Infrastructure (1948-1972)}

Modern development trajectories in the Ferlo essentially began in the late 1940s. Before then, the Ferlo was a temporary settlement area, inhabited for only part of the year by transhumant Fulani pastoralists [16]. Following the discovery of a massive Maastrichtian groundwater table in $1938\left( \pm 150,000 \mathrm{~km}^{2}\right.$ and 100/200 m deep), major mechanically operated deep borehole drilling was launched in 1948 [79]. The objectives were both economic and political-to increase livestock production and simultaneously sedentarize the Fulani pastoralist populations there and exclude them from the Senegal Valley intended for the development of irrigated agriculture [17]. By 1957, there were already 51 boreholes in the Ferlo, all state-owned [71]; today, there are over 320, 23\% of the total number in Senegal [54]. In keeping with studies pointing to the negative impact of borehole 
densification (see, e.g., $[17,71]$ )—i.e., by weakening social structures, or increasing pressure on fragile natural resources $[80,81]$, by increasing the population density of inhabitants on a year-round basis - boreholes and sedentarization policies participated in pushing the Ferlo beyond safe ecological boundaries [82].

During the 1950s, the colonial government began to create silvopastoral reserves with the goal of improving NRM, but also to continue sedentarizing Fulani people and strengthen the central government's stronghold in these marginal areas. Along with the ongoing borehole drilling program, the creation of these reserves participated in reinforcing pastoralism as the principal vocation of the Ferlo [65]. In 1960, Senegal became an independent nation, but this had surprisingly little impact on policies in the Ferlo. Characterized more by continuity rather than rupture [67], the newly independent Senegal pursued strong political centralization and sedentarization policies in the Ferlo.

In 1964, with the adoption of the Law on the National Domain, the State appropriated what it defined as "unoccupied land" (97\% of the total land), and introduced repressive measures to ensure its control over land and forest resources [16]. In 1968, the Dolly ranch was established in the southern portion of Linguère district as a space for promoting livestock breeding with the aim of modernizing the sector. The Dolly ranch illustrated the central government's perspective on livestock herding at that time: above all, it should meet the country's needs for meat and milk.

From the late 1960s onwards, the whole Sahel strip was confronted with periods of increasing inter-annual rainfall irregularities and aridity [51]. Environmental initiatives were sporadically launched here and there-for example, the Green Belt around Niamey in 1965 [61] and the Algerian Green Dam in 1971 [60] — but these actions were limited in geographic scope and effectiveness. In 1968, the African Convention on the Conservation of Nature and Natural Resources recognized the importance of environmental issues at the African scale, with Senegal reaffirming its commitment by ratifying the convention in 1971. Despite this, it remained an isolated policy and did not result in any immediate effects on development in the Ferlo. Thus, during this first period, the Ferlo remained relatively isolated and unaffected by events outside national boundaries.

\subsubsection{Climate Crises, Vulnerability and Development Aid (1972-1996)}

In the early 1970s, the Sahelian climate entered into a much hotter and drier phase, dramatically increasing the vulnerability of the underlying social-ecological systems, including those in the Ferlo [53]. This marked the beginning of the second period of development in the Ferlo. The most damaging and by far the most memorable drought in the Ferlo was the drought of 1973 which led to unprecedented crises, including in the death of large numbers of livestock and people $[49,55]$. The emerging Senegalese nation became increasingly dependent on international development aid. In the Ferlo, the distribution of food and feed substitutes for livestock was carried out by the Food and Agriculture Organization (FAO), the World Food Programme (WFP), and the World Bank (WB) [51]. However, the presence of international organizations also had negative consequences. The Structural Adjustment Plans (SAPs) imposed on Senegal by the International Monetary Fund (IMF) and the WB between 1979 and 1990 had a strong impact on development policies and practices throughout the country, including the Ferlo. Indeed, development actions were thereafter evaluated according to their financial profitability, leading to harmful social consequences such as the reinforcement of inequalities or the reduction in spending in the education and health sectors [83].

The early 1970s also marked the beginning of the politicization of the looming threat of desertification at the continental and global scales (interestingly, the term "desertification" was already being used by natural scientists to describe the Sahel back in the colonial times [50]). For example, at the continental scale, the creation of the Permanent Interstate Committee for Drought Control in the Sahel (CILSS, 1973) was an immediate response to the droughts in West Africa, setting up programs in various domains including rain-fed agriculture, environment, transport, and communication. In 1977, at the United Nations 
Conference on Desertification, a Plan of Action to Combat Desertification (PACD, 1977) was adopted, further fixating global attention on the far-reaching, long-term economic, social, and environment consequences of desertification. The year of 1977 also marked the beginning of the Green Belt Movement. Founded in Kenya by Wangari Maathai, massive tree planting would become the symbol for achieving community empowerment, gender equality, and social justice [59].

As international attention was clearly turned towards the Sahel in the 1970s, the Senegalese government continued to reinforce policies to promote pastoralism in the Ferlo. In 1972 two wildlife reserves, Ferlo Nord (Northern Ferlo, $6000 \mathrm{~km}^{2}$ ) and Ferlo Sud (Southern Ferlo, $6337 \mathrm{~km}^{2}$ ), were created with the aim of securing the natural resource base in the case of future crises. The state also created the Society for the Development of Livestock in the Silvopastoral Zone (SODESP), which intervened in the Ferlo between 1975 and 1985 to increase animal production, commercialize cattle at the national level, and organize the livestock sector based on regional resources [67]. Actors operating in the area also began diversifying with a growing presence of development-related NGOs. The creation of the Federation of NGOs of Senegal (FONGS) in 1976 illustrates the emergence, structuring, and coordination of these new actors at the national level.

From the early 1990s onwards, environmental concerns became center-stage worldwide, with scientists emphasizing the dire state of the Earth's biosphere and issuing doomsday scenarios if no immediate global action to combat climate change were to be taken. In 1992, the Rio Summit placed environment issues at the epicenter of all global challenges, and provided unprecedented resonance to the concept of sustainable development. At the continental level, the Sahara and Sahel Observatory (OSS), created the same year, initiated and facilitated partnerships on issues related to resource management and environment, with the implementation of international agreements on desertification, climate change, and biodiversity. In 1994, specific challenges related to the Earth's drylands gained visibility with the signing of the United Nations Convention to Combat Desertification [84]. The convention provided an official, highly-cited definition of desertification: "land degradation in arid, semi-arid and dry sub-humid areas resulting from various factors, including climatic variations and human activities". The impact of the convention was immediate in Senegal, at least in terms of policy discourse, with the adoption of the National Action Programme to Combat Desertification (PAN/LCD) in 1995.

This international focus for improved environmental governance led to the first in a long series of major state-run development programs in the Ferlo: the 1992-1999 Livestock Support Project (PAPEL). Its central feature was the establishment of the first pastoral unit (PU). The concept of PU refers to a geographical space where populations with the same economic interests live and use the same pastoral routes, water access points, and agricultural areas [70], and its NRM system supporting pastoral activities in the vicinity [85]. PUs give a certain degree of empowerment to local communities. Beyond the infrastructure provided, PUs are designed to ensure more sustainable management and use of pastoral resources (e.g., boreholes, ponds, fodder), and to gain better control of transhumant herders [69]. In this regard, the Ecological Monitoring Centre (CSE) has been playing a central role since its creation in 1986, by assisting development projects to establish PUs in the Ferlo and monitoring socioecological trends in their surroundings [85].

\subsubsection{Towards Polycentric Development with Growing Environmental Concerns (1996-2019)}

In 1996, Act II of the Law of Decentralization in Senegal marked the beginning of a new phase of development for the Ferlo. Whereas the Act I (1972) did create "rural communities" [20], Act II actually transferred the power and authority over to them in nine domains, one of which was NRM [86]. Decentralization laws were accompanied by administrative reconfiguration, such as the creation of the region of Matam in 2002. In order to "establish a more efficient administration that is closer to its citizens" [87], the Matam region was composed of three districts: Ranérou-Ferlo, Matam (the district of Matam is within the Matam region), and Kanel. According to the Ranérou-Ferlo District 
Livestock Inspector, since its creation, the Matam region has greatly benefited from a large number of development projects, including the construction of a paved road between Dakar and Matam (2004-2017) [18], thereby opening up access between Matam and the rest of the country.

In the early 2000s, the adoption of the Agro-Silvo-Pastoral Orientation Act (LOASP, 2004) constituted an important turning point for the Ferlo. For the first time, pastoralism, an activity often stigmatized as economically irrelevant and detrimental to the environment, was, from that time forward, recognized as a valuable economic activity in its own right. This paved the way for a number of projects aimed at securing, modernizing, and/or intensifying livestock herding in the Ferlo [19]. In order to harmonize these projects and establish common management practices in the silvopastoral zone, the Entente Ferlo was established in 2011, bringing together the regions of Louga and Matam, Saint-Louis, Kaffrine, and Tambacounda. The Entente Ferlo also participated in a decentralized cooperation initiative with the Rhône-Alpes region (France) and worked to combat climate change in the Ferlo by collaborating, for example, with the program TAAC-Senegal (P10) [54].

Since 2000, the Millennium Development Goals (MDGs, 2000) followed by the Sustainable Development Goals (SDGs, 2016), have been framing global development worldwide. Awarding the Nobel Peace Prize to Wangari Maathai in 2004 for the Green Belt Movement issued an incredibly strong statement internationally as to the importance of sustainable development, not only as an end in itself, but also as a vector of social justice and peace. Together, the MDGs and the SDGs identify the main humanitarian concerns and insist on the necessity to protect the environment and mobilize participatory methods as an integral part of development practice [62]. In this regard, Senegal is considered one of the leading countries on the African continent [88]. The adoption of the environment code in 2001, which imposes an environmental assessment for all development projects, highlights Senegal's dedication towards environment protection. More specifically in the Ferlo, Senegal's commitment to environmental restoration and well-being is demonstrated by its strong commitment to the African Great Green Wall (adoption in 2005, creation of the Senegalese National Green Wall Agency in 2008), and the launch of the ecovillage program [89], which participate in achieving the SDGs (e.g., No Poverty, Good Health and Well-being, Sustainable Cities and Communities, Life on Land). In 2016, there were 500 such villages in Senegal. Echoing the global trend for inclusive approaches, the Ferlo Biosphere Reserve was created in 2012. As part of the UNESCO Man and Biosphere Program, it covers over 2 million hectares and integrates pre-existing protected areas, such as the Ferlo wildlife reserves and other protected forests. More recently, the Emerging Senegal Plan [90] outlined innovative and ambitious orientations for the future development of the country through the modernization of rural equipment and transport, and an increase in agricultural production. In the northern part of the country, this plan includes the electrification of villages and the improvement of communication networks [91].

\subsection{Characterization and Dynamics of Development Projects in the Ferlo (1996-2019)}

In this section, we further explore the third period of development in the Ferlo with the objective of better understanding the evolution of environment-oriented development in the area. We base our analysis on a sample of twenty-five projects related to agriculture, pastoralism, and/or environment, which operated between 1996 and 2019 (Tables S1 and S2). On average, these projects lasted 4 years and 9 months, some being implemented over several phases, e.g., the PRODAM (P1, P4) and the PAPEL (P3), with budgets significantly increasing over the past 10 years. Although these projects are coordinated by a variety of stakeholders including NGOs, international institutions, and private donors, the national government is omnipresent not only as a donor, but as the principal decision-maker, despite decentralization politics. From a practical standpoint, the national government is often represented via a ministry or technical directory that is physically present at the local level. For example, in the Ranérou-Ferlo district, nearly $90 \%$ of the surface area is protected or classified, and under the authority of the Water, Forest, Hunting and Soil Conservation 
Directory district office. Here, any intervention, whether it be local or international, must have national government approval, especially with regards to infrastructure.

To classify the projects, we first established a typology according to their objectives. Seven main objectives were identified (Table 1). As illustrated in Figure 3, the evolution of these objectives points to an overall diversification over time. From 1996 to 2000, there was a relatively narrow focus on four objectives: pastoralism, agriculture, capacity building, and food security. From the early 2000s onwards, objectives began to diversify, with the relative importance of each varying over time. For example, agriculture which represented roughly $20 \%$ of the project objectives up until 2000 , gradually decreased and became inexistent since 2013.

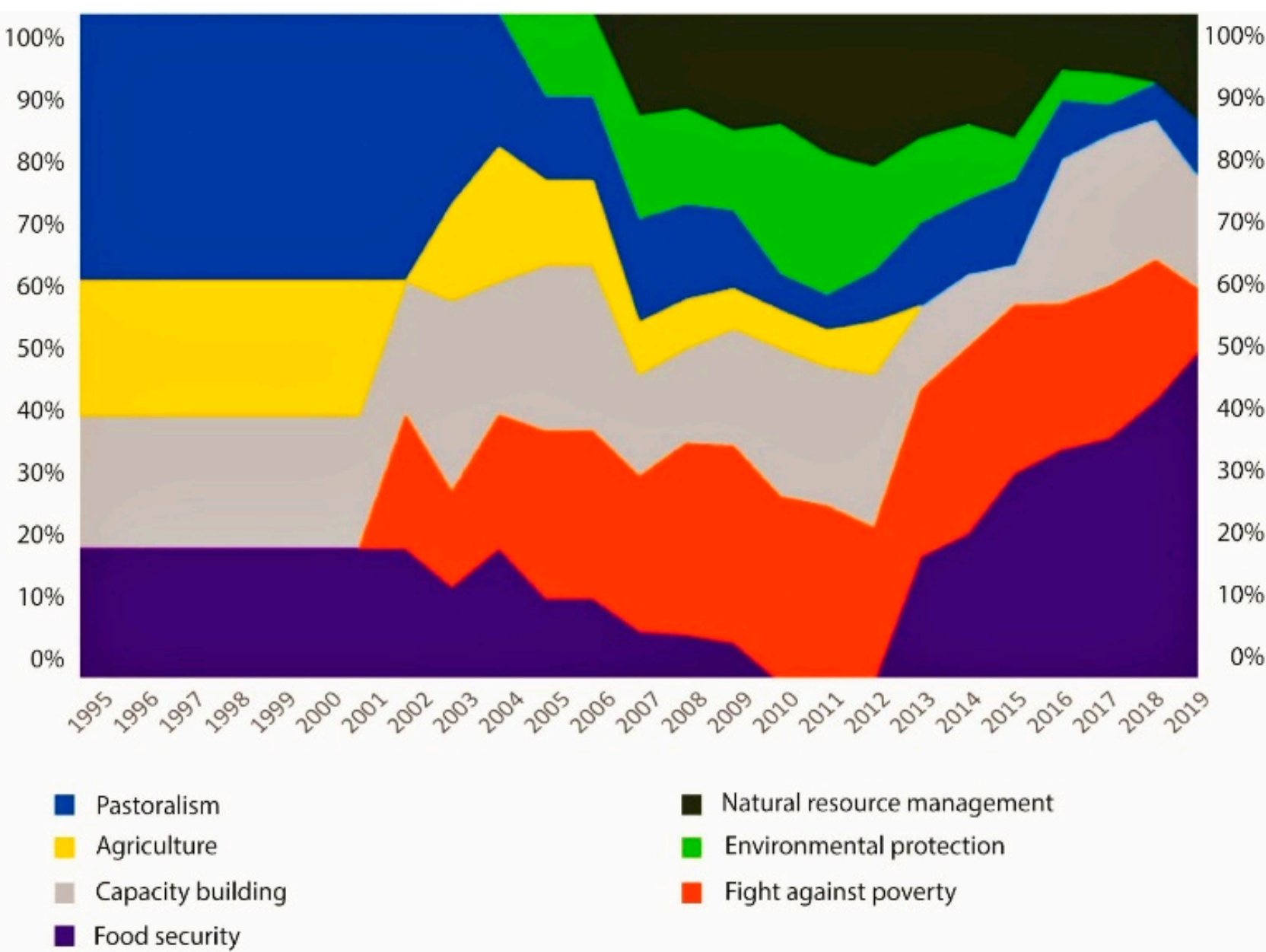

Figure 3. Objectives of environment-related development projects: 1996-2019. Based on the analysis of twenty-five projects, the figure shows the evolution of the relative importance of the different types of objectives over time.

The first clearly stated objective to be added to the originally narrow focus was the fight against poverty (in 2002). Indeed, from 2002 onwards, new projects such as the PAPEL II (P3) clearly displayed the objective of fighting poverty, echoing MDGs orientations. Fighting poverty has been a priority objective for a large number of projects in the area, such as the PN-PTFM (2008-2014, P8) or the PROGEDE 2 (2010-2017, P11). With regards to food security, after a period of relative importance (1996-2002), it disappeared in 2010 before re-emerging in 2012, and is currently the most targeted objective. Some of the most plausible explanations include the recurrent droughts in the Sahel in the early 2000s (Figure 2) and the global economic and food crisis that hit Senegal in 2008 [52]. For example, the PASA LOUMAKAF (2013-2019, P14) clearly aims to improve food security, especially 
since its main donor ( $80 \%$ of total budget) is the Global Agriculture and Food Security Program (PASA, 2017).

The next objectives to emerge were directly related to the general trend of increasing global environmental governance development associated with this period: environmental protection in 2005 and natural resource management in 2007. In 2011, environmental objectives were proportionally high for the 25 projects, present in up to $40 \%$ of projects. Some examples of projects with environmental objectives include the PGIES 2 (2007-2011, P7), which played a critical role in the creation of a UNESCO biosphere reserve in the Ferlo in 2012. Similarly, the FLCD RPS (P5), which operated between 2005 and 2011, carried out various actions involving environmental protection. However, in the past few years, the number of projects pursuing environmental objectives gradually decreased, in favor of improving food security.

For a more in-depth understanding of these projects, we identified project actions implemented to achieve their objectives. Eight different types of actions were identified (Table 2). The relative importance of these different types of project actions was determined over time (Figure 4). Several types of actions remained fairly constant over time. This is the case for construction and renovation of infrastructure and training, which account for $20 \%$ and $18 \%$ of development actions, respectively, over the entire period. At roughly $12 \%$, the importance of donations is also relatively constant throughout the entire period. One of the factors explaining the relative continuity of actions over time is that some of the larger, more recent projects are essentially sequels of past projects. This is the case, for example, of the PADAER (P13), which directly inherited the PRODAM (P1 and P4) and particularly its pastoral component, essentially through the rehabilitation and extension of PU networks. As explained by the person in charge of the PADAER, "the program did not come to create new things, it was designed to continue and consolidate the actions of previous projects. [... ] The differences are more at the level of execution and technical innovation".

The local population is highly dependent on natural resource for their livelihoods. However, strictly speaking, environmental protection and restoration actions began in 2002. Environmental actions reached their peak in 2007 (15\% of development actions), after which time their relative importance gradually decreased. As for awareness-raising actions, they appeared relatively recently (2007) and since then have occupied a relatively small but consistent proportion of the project actions. Actions in awareness-raising include a wide range of topics: bushfire management, agricultural practices, livestock vaccination, food storage, or health and hygiene. It is also important to note that actions are often interconnected within a project; some actions are designed to support others. For example, awareness-raising can be supported by infrastructures such as an information center for transhumance which enables people to gather and facilitate communication amongst stakeholders.

Finally, projects actions tend to diversify over time. This can be explained, at least in part, by the gradual increase in the number of projects and actors in the study area. This raises questions about if and how these projects collaborate amongst each other, which we examine in the following section. 


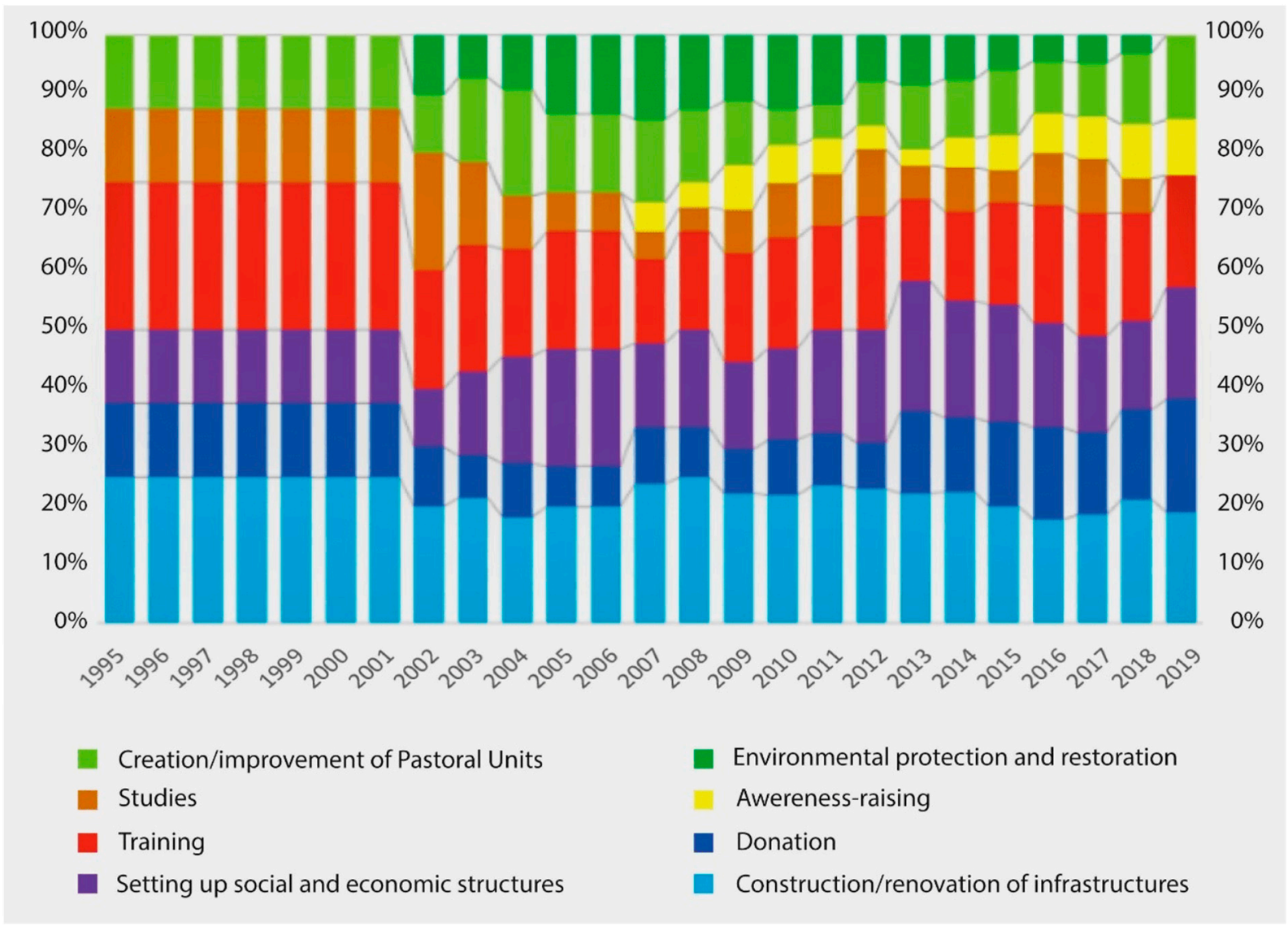

Figure 4. Development actions implemented by environment-related projects: 1996-2019. Based on the analysis of twentyfive projects, the figure shows the diversity and evolution of the relative importance of the different types of actions implemented by the sampled projects over time.

\subsection{Project Redundancy, Lack of Synergy and Relevance with Local Needs}

In an area characterized by a multitude of projects operating in similar domains and in overlapping municipalities, one would expect these projects to capitalize on each other's achievements, cooperate, and create synergies. However, our results tend to point to a rather different reality. We illustrate this point through an in-depth analysis of three projects carried out in the district of Ranérou-Ferlo, all of which aim to improve access to water: the PASA (P14), the PADAER (P13), and the PUDC (P20). At the time we gathered data (2017-2018), these three projects had come to an end. Both the PADAER and the PUDC have since been renewed (2019), and the results presented and discussed are only relevant for activities conducted before 2019.

Among other actions, these projects all construct and rehabilitate boreholes. Sixty years after the initial drilling efforts, the Ferlo is now covered by a rather dense network of boreholes. Although water access is considered a less urgent issue than in the past, boreholes continue to be built at high speed in the Ferlo by a variety of actors, despite negative long-term environmental effects (i.e., biomass and biodiversity loss) in close proximity to them $[16,17,58,67]$. They also generate conflict amongst local people for control over this key resource, resulting in increasing environmental injustice within local populations [68].

The three projects are differentially embedded into the local socio-political context, each one with a different interlocutor. This is one of the factors that participates in the apparent lack of coherence amongst them. The PUDC (P20), for instance, works mainly with locally elected officials (mayors and district council members) and administrative representatives (prefects, sub-prefects, and governors), whereas the PASA (P14) and the 
PADAER (P13) interact directly with extension services (i.e., district livestock inspector or water and forest ministry officials). In general, local actors interviewed stressed a need for more coherence amongst projects. One district livestock inspector stated that "program coordinators working in the district do not meet once every six months, or even once a year, to discuss the activities they are doing". A municipal secretary of Oudalaye (a commune in the Ranérou-Ferlo district) mentioned the prefect's will to set up a multi-stakeholder forum: "[the prefect] wanted to organize this, but I think that so far this meeting has not been able to take place. We hope that when it does take place, we, as local authorities, will be involved to say what we want to say about the network, the sectors of activity and the projects".

Another major limitation to effective collaboration is the fundamentally different visions of the Ferlo held by the development actors involved in the different projects. According to a high-level official of the PUDC (P20), "[the project] should sedentarize the populations $(\ldots)$ and get the population to develop activities that tend to be more productive than extensive". Conversely, a high-level official of the PADAER (P13) explained that "contrary to what some people think, the objective is not to settle people down; pastoralism and transhumance are part of the people's culture. There is still the problem of grazing lands, as pastoral policies are very limited". The PADAER (P13) therefore considers pastoralism as a way of life that must be taken into account in the design of development projects. These fundamental differences limit the possibilities for collaboration amongst actors in the Ferlo.

There are also issues of power inequity at play within the development landscape in the Ferlo. Local actors often describe a trend by which the bigger projects tend to phagocytose the actions of smaller ones, and as a result, capture all of the social and political benefits. As expressed by a PASA (P14) official: "we were supposed to drill a borehole in Téssékéré, but the PUDC told us that they were better equipped and that they were going to do it". Another PASA (P14) official pointed out that "they [the PUDC] are more powerful than we are; it's the president's baby (laughs) so we don't waste time saying 'no, it's us'". These power imbalances contribute to the frustration among development actors and confusion amongst project beneficiaries.

Finally, despite the narrative around empowerment of local communities (through the creation of PUs for example), there still appears to be significant mismatch between projects and local needs. A Ranérou resident and beneficiary of the PASA (P14) describes the following situation: "The village chief came to inform us that a project was going to fund sheep pens and hen houses, but I didn't know the project's name, so like others I put my name on a list. My name was drawn and people came to build a henhouse at my house; I would have preferred to have a sheep barn but I couldn't choose".

\section{Discussion}

\subsection{Projects Promoting Environmental Stewardship Are Recent in the Ferlo}

Environmental stewardship can be defined as the set of actions taken by individuals, groups, or networks of actors, with various motivations and levels of capacity, to protect, care for, or responsibly use the environment in pursuit of environmental and/or social outcomes in diverse social-ecological contexts [38]. In order to inform current and future large-scale initiatives to promote principles of environmental stewardship in the Ferlo, we initially sought to identify common denominators of success (and/or failure) of past development projects characterized by a strong environmental focus. However, despite extensive literature searches, it soon became apparent that projects with a strict environmental focus (i.e., protection, conservation, restoration) were relatively recent in the Ferlo. That said, it is important to note that tree planting activities have been regularly carried out throughout Senegal ever since the colonial period $[63,66]$. By analyzing multi-scale historical events and their impact in the Ferlo, it became clear that there was actually no real need to promote environmental projects (few year-round inhabitants, little-to-no pressure on natural resources, absence of any severe climatic shocks) during the first period of de- 
velopment described herein. The extreme vulnerability of the fragile Sahelian ecosystems was only revealed during the second period of development (beginning in the early 1970s) as a result of repetitive, severe droughts. These climate shocks, coupled with increased year-round settlements and livestock as a result of permanent water access, participated in land degradation. Only then did it become apparent that environmental health was intimately linked to human well-being, thereafter setting the scene for the onslaught of environment-targeted projects for decades to come. Up until the 1990s, and to a large extent even now, the main development objectives in the Ferlo have focused on supplying access to basic needs: healthcare, education, and water. This suggests that environmental concerns have often been relegated to a secondary priority, and there is a real challenge to think holistically about development and environmental objectives together. This was, for example, the case in the South African environment and development program called "Working for Wetlands", in which difficulties were encountered in achieving the dual goal of poverty alleviation and wetland conservation [73]. In this study, we found that environmental actions were often limited to reforestation and/or construction of fenced-in plots. These actions are often ill-adapted to both the ecological and social realities of the area $[57,92]$ and as a result, often fail to fully achieve their objectives. Moreover, if environmental concerns appear secondary and/or ill-adapted in the Ferlo, it is partly because the very framework in which development is designed and implemented is contradictory with environmental and restoration goals [42]. The case in the Ferlo echoes the challenge of the development paradigm based on neoliberal logic. In this sense, we agree with Barry's criticism of carbon-based development in relation to capitalism [45]. There is a real challenge to avoid development actions that result in policy misfits [37]. In order to do so, it is essential to strengthen systemic and inclusive approaches, and not to consider each issue separately, concerning, for instance, health (see One Health initiative, [93]) or climate change and biodiversity loss [94]. Finally, despite a dominant environmental discourse at the global scale, only $2 \%$ of the total international aid budget destined for the Sahelian countries are routinely allocated to environmental protection [95].

\subsection{An Exclusive Focus on Pastoralism in the Ferlo: A Double-Edged Sword?}

The designation of the Ferlo as a silvopastoral zone dedicated to pastoralism as the principal source of livelihoods dates back to the colonial period [65]. Ever since, pastoralism has been the focus of all territorial planning strategies, and the onslaught of development projects since the 1990s have been no exception. The idea that the Ferlo is naturally made for pastoral activity remains unanimously shared by politicians, NR managers, development actors, and local populations. For some, it is "the ecosystem that dictates this" (the PASA national coordinator). For Fulani people, pastoralism is "[their] identity, [they] found it here and [they] continue it without knowing the fundamental reasons [...] life revolves around livestock herding, the vocation of livestock herding is part of [them]" (the deputy mayor of Ranérou). Although these statements are extremely revealing and well-anchored in tradition, the fact that the Ferlo has become synonymous with pastoralism could also be considered as a double-edged sword. On the one hand, many have demonstrated the resilience of pastoral systems in resource-constrained, social-ecological systems, and even more so in the context of global changes and their associated sustainability challenges $[44,48,85,96]$. On the other hand, the mismatch between transhumance regimes and centralized states often complicate access to basic services, such as education and health (e.g., [97-99]), which in return affects livelihoods. Reflecting on current pastoral systems in the Sahel necessarily stirs up age-old debates about overgrazing and land degradation. There are those who support the idea that extensive livestock herding is detrimental to the environment (e.g., [100]), and those who hold the opposite view (e.g., [101,102]). Herein, it is not our intention to take position one way or another. We believe that in the current context, the vision that pastoralism in the Ferlo is the one and only way forward may (and should be) challenged, taking into consideration the multiplicity of stakeholders present within the climatic change context. The idea is not to abandon pastoralism, which would be both socially and ecologically 
irrelevant [103], but limiting the Ferlo to its pastoral identity could potentially lock the system into a narrow path and reduce the option space for potential adaptations, innovations, and transformations in the zone [104]. Stakeholders at different levels could conceivably challenge the dogma of the pastoral vocation of the Ferlo, and collectively search for a new equilibrium between pastoralism and other potential income-generation activities; in other words, explore alternative paths for development. Such processes are already starting to take place, albeit at a rather small scale. One example is the resilience thinking- based participatory planning exercise carried out in the Ranérou-Ferlo district by Perrotton et al [105] which, based on the "Wayfinder" guidebook, uncovered a wide range of aspirations for the future far beyond traditional herding.

\subsection{Decentralization, Participation and Trust in Local Communities}

Since the 1970s, the Senegalese government has engaged in a gradual process of decentralization. Although it is widely accepted that there is a transitive relationship between decentralization and local development [106], there is still much progress to be made to improve local development and autonomy. Decentralization in Senegal has been generally criticized because it does not provide local actors with sufficient means neither in terms of financial capacity nor self-management [86], leading to a tangled web of competences at multiple levels and complicating decision-making [19]. Herein, we shed light on two key features of development governance in the Ferlo that need further consideration. First is the lack of synergy both amongst projects and between projects and stakeholders. Exchanges and consultation amongst projects and stakeholders at the local level need to become more systematic; this could be facilitated by the creation of a multi-level, multi-stakeholder, governing body that would have the official mandate to oversee development in the zone. Second is the fact that the central government still plays a dominant role in most of the large-scale development projects. This tends to confirm our second hypothesis, which stated that top-down approaches are still used in the implementation of development projects, despite decentralization. As Shin et al. [74] showed using the World Bank Independent Evaluation Group (WBIEG) project data, an increased number of non-state actor participants tends to improve project outcomes, as long as there are not too many actors involved (otherwise it leads to negative outcomes). Our paper suggests that the efforts made in Senegal towards decentralization and diversification are not fruitful so far, at least concerning the Ferlo, but this result could be extended to other regions of Senegal and neighboring countries. For instance, it has been shown more generally in Western Africa that decentralization was mainly a matter of discourse. It is something more akin to "deconcentration", where the State continues to exercise its authority over the national territory [107]. Other studies point to other difficulties of the decentralization process; for example, in Indonesia, where it took a long time for decentralization to produce the desired results [108]. In any case, the relationships between decentralization and development in developing countries are complex and still a matter of debate $[109,110]$. Participatory approaches are not new in development studies [111,112], as well as in conservation studies, better known as community-based conservation [113-115]. However, their implementation seems to encounter many obstacles in southern countries and the outcomes are often criticized [116]. Taking into account local populations and their knowledge seems necessary to answer both socioeconomic and environmental issues $[41,64]$, even if participatory development and community-based conservation can be disconnected [117]. The scientific literature provides positive examples on that matter; for instance, the role of Aboriginal participation in mine development in Canada [43], or the meta-analysis of 116 published case studies on common resource management regimes in Africa, America, and Asia conducted by Oldekop et al. [47]. In the case of the Ferlo, one cannot help but wonder to what extent the integration of local knowledge of Fulani pastoralists could better guide development actions, an issue that seems to have received little consideration to date. 


\subsection{Towards a More Resilience Thinking-Based Development Paradigm in the Ferlo?}

Since the 2010s, a new era of development has been emerging internationally, one in which the concept of resilience has become central, at least in terms of institutional, global discourse. This new era is marked by the political will to change the ways of thinking about and executing development. It is characterized by complex social-ecological system analyses that consider interacting social and environmental phenomena, system dynamics in the long term, and active participation and co-learning of actors at all levels throughout the development "process". Several attempts to apply resilience thinking in the development context have been described [105,118]. Despite growing enthusiasm internationally, resilience-based approaches are just starting to be tested, and have yet to trickle down to any great extent in the Ferlo. However, development initiatives based on resilience thinking and systemic analyses have become more necessary than ever in the area. One previously mentioned example is the unbridled multiplication of boreholes over the past 70 years. Although water access is a basic human right and a sustainable development goal (SDG 6: Clean Water and Sanitation), the continued drilling raises serious questions for future development in the Ferlo and the resilience of its social-ecological systems. Beyond the social consequences described elsewhere in this paper, the sustainability of water extraction and use of the Maastrichtian deep aquifer is of serious concern. It is the most important source of drinking water in Senegal and over a thousand boreholes already pump water up [119]. As Peiry and Voldoire [120] and Kane et al. [119] warn, the aquifer consists partly of fossil water and data about the recharging dynamics are either non-representative or inexistent. As water use increases, so do chloride and fluoride content, sometimes beyond acceptable drinking water thresholds. We join their claim about the critical need to implement large-scale groundwater assessments in the area, and to develop adapted water management policies.

\section{Conclusions}

In order to understand the development trajectories in the Ferlo at the local level, we deemed it necessary to take into account the complexity and impacts of phenomena taking place at several scales. Whether it be a climatic episode, a political decision, or a modification in an institutional framework, these key events are essential for understanding the dynamics at play in relation to development trajectories. If a multi-scale historical perspective does not allow us to predict with certitude how the Ferlo will respond to shocks and events in the future, this overall vision is certainly helpful in understanding system behavior and guiding present ambitious environmental development actions-for one, the Great Green Wall. We believe that a multi-scale historical analysis of a given area should be a prerequisite for implementing development initiatives carried out in other areas.

A new phase of development that relies more heavily on the resilience paradigm could generate hope for the Ferlo of the future. The principles of resilience propose fruitful avenues for innovative thinking about the development process [121]. Past projects are generally characterized by a set of specific actions that do not sufficiently take into account social realities or effects in the long term. In line with our third hypothesis, we also showed that the lack of a consultation framework and the lack of intermediaries between different scales have a significant negative impact on development initiatives. To remedy these drawbacks, new approaches that integrate polycentricity, participation, and connectivity can be tested and implemented. They could accompany the ongoing decentralization process and participate in remedying age-old "project mismatch" that arises from the oversized gap (geographic and social) between decision-makers and project beneficiaries.

To better report on development initiatives, an exhaustive database would have been necessary, but unfortunately, critical information was lacking and/or unavailable; even in the field, many past development projects have long been forgotten without leaving a trace. This fact underlines the flaw in these kinds of initiatives, and the very fact that they are still needed decades later can be seen as evidence of relative failure. Indeed, the success of development project depends, at least in part, on their ability to continue beyond the project 
life span. That implies creating a climate of agency at the local level. However, the tools to evaluate subtle parameters of project success, such as agency, are often lacking. Projects produce reports at regular intervals to account for their activities, but we found it difficult to measure potential gaps between report content and real achievements [122]. This would require including neutral evaluations produced by external experts and scientists as a pre-requisite to any project.

Supplementary Materials: The following are available online at https:/ /www.mdpi.com/article/10 $.3390 /$ land10070755/s1. Table S1: Grey literature used in this study. Table S2: General features of development projects analyzed in this study.

Author Contributions: Conceptualization, H.M., A.P., A.K. and D.G.; methodology, H.M. and A.K.; formal analysis, H.M., A.P., A.K. and D.G.; project admin and funding acquisition, D.G., investigation, H.M. and D.G.; resources, D.G.; data curation, H.M., A.P., A.K. and D.G.; writing-original draft preparation, H.M., A.P., A.K. and D.G.; writing-review and editing, H.M., A.P., A.K. and D.G.; supervision, D.G., A.P. and A.K. All authors have read and agreed to the published version of the manuscript.

Funding: This research was funded by the French National Research Agency (ANR) under the project name "Future Sahel" (ANR15-CE03-0001).

Institutional Review Board Statement: Not applicable.

Informed Consent Statement: Informed consent was obtained from all subjects involved in the study.

Acknowledgments: The authors wish to thank Birane Cissé for providing the map in Figure 1. Many thanks to Moctar Bocar Sall, for fruitful discussions and logistical support. We warmly thank Karine Ginoux and Sophie Drame who always ensure that our field missions run as smoothly as possible from an administrative and logistic standpoint. We also want to acknowledge all of the development actors and project beneficiaries who kindly spent time discussing development in the Ferlo with us. We are extremely grateful to the CNRS Observatoire Hommes-Milieux Tessékéré (as part of the Labex DRIIHM ANR-11-LABX-0010: Laboratoire d'Excellence Dispositif de Recherche Interdisciplinaire sur les Interactions Hommes-Milieux) and the French National Research Agency (ANR) for funding "Future Sahel" (ANR15-CE03-0001). Finally, we would like to thank the reviewers of the manuscript for their comments that have helped us to significantly improve it.

Conflicts of Interest: The authors declare no conflict of interest. The funders had no role in the design of the study; in the collection, analyses, or interpretation of data; in the writing of the manuscript, or in the decision to publish the results.

\section{References}

1. DDD. The DDD Manifesto on Doing Development Differently. 2015. Available online: https://buildingstatecapability.com/the-dddmanifesto/ (accessed on 15 August 2018).

2. UNDESA. World Population Prospects; United Nations Department of Economic Social Affairs Population Division: New York, NY, USA, 2015.

3. Asadullah, M.N.; Savoia, A. Poverty Reduction during 1990-2013: Did Millennium Development Goals Adoption and State Capacity Matter? World Dev. 2018, 105, 70-82. [CrossRef]

4. Driscoll, D.A.; Bland, L.M.; Bryan, B.A.; Newsome, T.M.; Nicholson, E.; Ritchie, E.G.; Doherty, T.S. A Biodiversity-Crisis Hierarchy to Evaluate and Refine Conservation Indicators. Nat. Ecol. Evol. 2018, 2, 775-781. [CrossRef]

5. Leighton, M. Desertification and migration. In Governing Global Desertification; Routledge: London, UK, 2006 ; pp. 63-78.

6. Cohen, A.J.; Brauer, M.; Burnett, R.; Anderson, H.R.; Frostad, J.; Estep, K.; Balakrishnan, K.; Brunekreef, B.; Dandona, L.; Dandona, R.; et al. Estimates and 25-Year Trends of the Global Burden of Disease Attributable to Ambient Air Pollution: An Analysis of Data from the Global Burden of Diseases Study 2015. Lancet 2017, 389, 1907-1918. [CrossRef]

7. Robert, K.W.; Parris, T.M.; Leiserowitz, A.A. What Is Sustainable Development? Goals, Indicators, Values, and Practice. Environ. Sci. Policy Sustain. Dev. 2005, 47, 8-21. [CrossRef]

8. Bierschenk, T.; Chauveau, J.-P.; Olivier de Sardan, J.-P. (Eds.) Brokers in Development: African Villages in Search of Projects; Collection "Hommes et sociétés"; Karthala: Paris, France; Association Euro-Africaine Pour L'anthropologie du Changement Social et du Développement: Mainz, Germany, 2000; ISBN 978-2-84586-013-1.

9. Mikulcak, F.; Haider, J.L.; Abson, D.J.; Newig, J.; Fischer, J. Applying a Capitals Approach to Understand Rural Development Traps: A Case Study from Post-Socialist Romania. Land Use Policy 2015, 43, 248-258. [CrossRef]

10. Helfgott, A. Operationalising Systemic Resilience. Eur. J. Oper. Res. 2018, 268, 852-864. [CrossRef] 
11. Brett, E.A. Participation and Accountability in Development Management. J. Dev. Stud. 2003, 40, 1-29. [CrossRef]

12. Ebrahim, A. Accountability In Practice: Mechanisms for NGOs. World Dev. 2003, 31, 813-829. [CrossRef]

13. Winters, M.S. Targeting, Accountability and Capture in Development Projects. Int. Stud. Q. 2014, 58, 393-404. [CrossRef]

14. Rempel, R. Development History and Postcolonial African Experience. In The Palgrave Handbook of African Colonial and Postcolonial History; Palgrave Macmillan: New York, NY, USA, 2018.

15. Aubert, P.-M. Development projects and changes in public action. Rev. Tiers Monde 2014, 220, 221-237. [CrossRef]

16. Barral, H. The Ferlo of Boreholes: Past and Present Management of Pastoral Space: A Study of Human Geography; ORSTOM: Dakar, Senegal, 1982; Volume 85.

17. Ickowicz, A.; Akpo, E.; Ancey, V.; André, D.; Diop, A.T.; Leclerc, G.; Touré, I.; Touré, O.; Wane, A. Case Study $n^{\circ} 2:$ The Experience of Pastoral Drilling in the Ferlo, a Development Factor or a Socio-Technical Impasse and a Factor of Desertification? 2012. Available online: https: / / agritrop.cirad.fr/564286/ (accessed on 16 July 2021).

18. National Statistics and Demography Agency (ANSD). Senegal's Economic and Social Situation in 2016. 2019. Available online: https:/ / www.ansd.sn/ressources/ses/SES_2016_fin.pdf (accessed on 16 July 2021).

19. Ninot, O. Livestock and Territory in the "Ferlo", a Pastoral Zone in Northern Senegal. Mission Report. 2007. Available online: https:/ / www.jstor.org/stable/4005874 (accessed on 17 July 2021).

20. Piveteau, A. Decentralization and local development in Senegal. Chronicle of a hypothetical couple. Rev. Tiers Monde 2005, 46, 71-93. [CrossRef]

21. Yevjevich, V.; Starosolszky, Ö. Controversies between Water Resources Development and Protection of the Environment. J. Hydraul. Res. 1998, 36, 135-138. [CrossRef]

22. Liu, J.; Dietz, T.; Carpenter, S.R.; Folke, C.; Alberti, M.; Redman, C.L.; Schneider, S.H.; Ostrom, E.; Pell, A.N.; Lubchenco, J.; et al. Coupled Human and Natural Systems. AMBIO J. Hum. Environ. 2007, 36, 639-649. [CrossRef]

23. Berkes, F.; Colding, J.; Folke, C. (Eds.) Navigating Social-Ecological Systems: Building Resilience for Complexity and Change; Cambridge University Press: Cambridge, UK, 2002; ISBN 978-0-521-06184-1.

24. McGinnis, M.; Ostrom, E. Social-Ecological System Framework: Initial Changes and Continuing Challenges. Ecol. Soc. 2014, 19. [CrossRef]

25. Land and Water Rights in the Sahel: Tenure Challenges of Improving Access to Water for Agriculture; Cotula, L.; Drylands Programme (Eds.) Issue Paper Drylands Programme; International Institute for Environment and Development, Drylands Programme: London, UK, 2006; ISBN 978-1-84369-604-9.

26. Brockington, D.; Igoe, J.; Schmidt-Soltau, K. Conservation, Human Rights, and Poverty Reduction. Conserv. Biol. 2006, 20, 250-252. [CrossRef] [PubMed]

27. Barr, C.M.; Sayer, J.A. The Political Economy of Reforestation and Forest Restoration in Asia-Pacific: Critical Issues for REDD+. Biol. Conserv. 2012, 154, 9-19. [CrossRef]

28. Mansourian, S.; Parrotta, J. (Eds.) Forest Landscape Restoration: Integrated Approaches to Support Effective Implementation; Routledge: London, UK, 2018; ISBN 978-1-315-11187-2.

29. Blanc, G. The Invention of Green Colonialism: Ending the Myth of the African Eden; Flammarion: Paris, France, 2020; ISBN 978-2-08-150439-4.

30. Catalano, A.S.; Lyons-White, J.; Mills, M.M.; Knight, A.T. Learning from Published Project Failures in Conservation. Biol. Conserv. 2019, 238, 108223. [CrossRef]

31. Dia, A.; Duponnois, R. (Eds.) The Great Green Wall Africa Project: Concepts and Implementation; IRD, Institut de Recherche Pour le Développement: Marseille, France, 2010; ISBN 978-2-7099-1696-7.

32. Dia, A.; Duponnois, R. (Eds.) The Great Green Wall: Capitalization of Research and Valorization of Local Knowledge; Synthèses; IRD Éditions: Marseille, France, 2013; ISBN 978-2-7099-1788-9.

33. Magrin, G.; Mugelé, R. The Loop of the Anthropocene in the Sahel: Nature and Societies in the Face of Large Environmental Projects (Great Green Wall, Saving Lake Chad). Belgeo 2020, 3. [CrossRef]

34. Goffner, D.; Sinare, H.; Gordon, L.J. The Great Green Wall for the Sahara and the Sahel Initiative as an Opportunity to Enhance Resilience in Sahelian Landscapes and Livelihoods. Reg. Environ. Chang. 2019, 19, 1417-1428. [CrossRef]

35. Olivier de Sardan, J.-P. Anthropology and Development: Essay in Socio-Anthropology of Social Change; Hommes et Sociétés; APAD: Marseille, France, 1995; p. 221. ISBN 978-2-86537-589-9.

36. Leloup, F.; Moyart, L.; Pecqueur, B. Local Development in West Africa: What Reality(s) are Possible? Mondes Dév. 2003, 124, 95. [CrossRef]

37. Bunce, M.; Brown, K.; Rosendo, S. Policy Misfits, Climate Change and Cross-Scale Vulnerability in Coastal Africa: How Development Projects Undermine Resilience. Environ. Sci. Policy 2010, 13, 485-497. [CrossRef]

38. Bennett, N.J.; Whitty, T.S.; Finkbeiner, E.; Pittman, J.; Bassett, H.; Gelcich, S.; Allison, E.H. Environmental Stewardship: A Conceptual Review and Analytical Framework. Environ. Manag. 2018, 61, 597-614. [CrossRef] [PubMed]

39. Belem, G. Sustainable development in Africa: A process under constraints Experience of the Malian mining industry. VertigO 2006. [CrossRef] 
40. Epstein, G.; Vogt, J.; Mincey, S.; Cox, M.; Fischer, B. Missing Ecology: Integrating Ecological Perspectives with the Social-Ecological System Framework. Int. J. Commons 2013, 7, 432-453. [CrossRef]

41. Bridgewater, P.; Régnier, M.; García, R. Implementing SDG 15: Can Large-Scale Public Programs Help Deliver Biodiversity Conservation, Restoration and Management, While Assisting Human Development? Nat. Resour. Forum 2015, 39, 214-223. [CrossRef]

42. Rîșteiu, N.T.; Creţan, R.; O’Brien, T. Contesting Post-Communist Economic Development: Gold Extraction, Local Community, and Rural Decline in Romania. Eurasian Geogr. Econ. 2021, 1-23. [CrossRef]

43. Fidler, C. Increasing the Sustainability of a Resource Development: Aboriginal Engagement and Negotiated Agreements. Environ. Dev. Sustain. 2009, 12, 233-244. [CrossRef]

44. Biggs, R.; Schlüter, M.; Schoon, M.L. Principles for Building Resilience: Sustaining Ecosystem Services in Social-Ecological Systems; Cambridge University Press: Cambridge, UK, 2015; ISBN 978-1-316-29992-0.

45. Barry, J. Climate change, 'the cancer stage of capitalism' and the return of limits to growth: Towards a political economy of sustainability. In Climate Change and the Crisis of Capitalism: A Chance to Reclaim Self, Society and Nature; Routledge: New York, NY, USA, 2012; pp. 129-143.

46. Loreau, M. Reconciling Utilitarian and Non-Utilitarian Approaches to Biodiversity Conservation. Ethics Sci. Environ. Politics 2014, 14, 27-32. [CrossRef]

47. Oldekop, J.A.; Bebbington, A.J.; Brockington, D.; Preziosi, R.F. Understanding the Lessons and Limitations of Conservation and Development. Conserv. Biol. 2010, 24, 461-469. [CrossRef]

48. Leach, M.; Raworth, K.; Rockström, J. Between Social and Planetary Boundaries: Navigating Pathways in the Safe and Just Space for Humanity; World Social Science Report 2013: Changing Global Environments; UNESCO: Paris, France, 2013; pp. 84-89. [CrossRef]

49. Durand, J.-H. About the drought and its consequences in the Sahel. Les Cahiers d'outre-mer 1977, 30, 383-403. [CrossRef]

50. Aubréville, A. Climates: Forests and Desertification in Tropical Africa; Société D'éditions Géographiques, Maritimes et Coloniales: Paris, France, 1949.

51. Santoir, C. Pastoral societies in Senegal facing the 1972-1973 drought: Responses to the crisis and degree of recovery two years later: The case of the Peul of "Galodjina". In Pastoral and Agricultural Strategies of Sahelians during the 1969-1974 Drought; Travaux et Documents de Géographie tropicale; CEGET: Talence, France, 1977; pp. 17-59.

52. Bonnecase, V.; Brachet, J. Sahelian crises between local perceptions and international managemen. Polit. Afr. 2013, 130, 5-22.

53. Le Houerou, H.N. The Rangelands of the Sahel. J. Range Manag. 2006, 33, 41. [CrossRef]

54. Renewable Energy Environment and Solidarity Group (GERES). Atlas of Territorial Vulnerabilities of the Ferlo to Climate Change. ClimTerr. 2013. Available online: https://www.geres.eu/wp-content/uploads/2019/10/atlas-geres-climterr-web.pdf (accessed on 17 July 2021).

55. Fall, A. From the Ferlo to the Groundnut Basin (Senegal): Analysis of the floristic composition of the vegetation considered as a resource and as an indicator of socio-environmental changes. Physio-Géo Géographie Phys. Environ. 2017, 65-91. [CrossRef]

56. Harsch, E. Strengthening Bonds in the Sahel. Afr. Renew. 2018, 32, 24-25. [CrossRef]

57. Wade, T.I.; Ndiaye, O.; Mauclaire, M.; Mbaye, B.; Sagna, M.; Guissé, A.; Goffner, D. Biodiversity Field Trials to Inform Reforestation and Natural Resource Management Strategies along the African Great Green Wall in Senegal. New For. 2018, 49, 341-362. [CrossRef]

58. Vincke, C.; Diédhiou, I.; Grouzis, M. Long Term Dynamics and Structure of Woody Vegetation in the Ferlo (Senegal). J. Arid Environ. 2010, 74, 268-276. [CrossRef]

59. Hunt, K.P. “It's More Than Planting Trees, It's Planting Ideas": Ecofeminist Praxis in the Green Belt Movement. South. Commun. J. 2014, 79, 235-249. [CrossRef]

60. Sahraoui, B. Critical assessment of the green dam in Algeria. Sécheresse 1995, 6, 247-255.

61. Manzo, S. Niamey's Green Belt. Available online: http:/ / www.thewomenstorch.com/fr/2016/11/23/ceinture-verte-de-niamey/ (accessed on 2 September 2020).

62. Boutinot, L. The complexity of decentralization. Example of forest resource management in Senegal. Bull. APAD 2001. [CrossRef]

63. Ribot, J.C. History of Forest Management in West Africa: Or: How "Science" Excludes Farmers; International Institute for Environment and Development, Programme Zones Arides: London, UK, 2001.

64. Schweizer, D.; van Kuijk, M.; Ghazoul, J. Perceptions from Non-Governmental Actors on Forest and Landscape Restoration, Challenges and Strategies for Successful Implementation across Asia, Africa and Latin America. J. Environ. Manag. 2021, 286, 112251. [CrossRef]

65. Cesaro, J.D.; Magrin, G.; Ninot, O. Atlas of Livestock in Senegal: Businesses and Territories; PRODIG: Paris, France, 2010.

66. Grenier, P. The Peul of the Ferlo. Les Cahiers d'outre-mer 1960, 13, 28-58. [CrossRef]

67. Touré, O. A Changing Pastoral Society under the Effect of Development Policies: The Peul of the Ferlo from the Beginning of the Century to the Present Day; Unité Socio-Économique Démographie, Institut Sénégalais de Recherches Agricoles: Dakar, Sénégal, 1987.

68. Juul, K. Power, pastures and politics: Boreholes and decentralisation of local resource management in northern Senegal. In Politics, Property and Production in West African Sahel: Approaches to Natural Resource Management; Elanders Gotab: Stockholm, Sweden, 2001; pp. 57-74. 
69. Wade, C.T. Development of Livestock in the Forest-Pastoral Zone: The Contribution of Pastoral Units. Available online: https: / / www.google.com/search?q=THIOUNE+Abdou+Aziz $\% 2 C+$ Guide + m\%C3\%A9thodologique+de+mise+en+oeuvre+ et+d $\% 27$ animation+des+Unit $\% \mathrm{C} 3 \% \mathrm{~A} 9 \mathrm{~s}+$ Pastorales+au+S $\% \mathrm{C} 3 \% \mathrm{~A} 9 \mathrm{n} \% \mathrm{C} 3 \% \mathrm{~A} 9 \mathrm{gal} \% 2 \mathrm{C}+$ Agronomes+et+V $\% \mathrm{C} 3 \% \mathrm{~A} 9 \mathrm{t} \% \mathrm{C} 3 \% \mathrm{~A} 9$ rinaires+sans+Fronti $\% \mathrm{C} 3 \% \mathrm{~A} 8 \mathrm{res}+(\mathrm{AVSF}) \% 2 \mathrm{C}+\mathrm{CSE} \% 2 \mathrm{C}+$ Minist $\% \mathrm{C} 3 \% \mathrm{~A} 8 \mathrm{re}+\mathrm{de}+1 \% 27 \% \mathrm{C} 3 \% \mathrm{~A} 91$ evage+et+des+productions+ animales+du+S\%C3\%A9n\%C3\%A9gal\%2C+2017\&rlz=1C1CHBF_frFR906FR906\&oq=THIOUNE+Abdou+Aziz $\% 2 C+G u i d e+$ $\mathrm{m} \% \mathrm{C} 3 \%$ A9thodologique+de+mise+en+oeuvre+et+d $\% 27$ animation+des+Unit $\% \mathrm{C} 3 \% \mathrm{~A} 9 \mathrm{~s}+\mathrm{Pastorales}+\mathrm{au}+\mathrm{S} \% \mathrm{C} 3 \% \mathrm{~A} 9 \mathrm{n} \% \mathrm{C} 3 \% \mathrm{~A} 9$ gal $\% 2 \mathrm{C}+$ Agronomes+et $+\mathrm{V} \% \mathrm{C} 3 \% \mathrm{~A} 9 \mathrm{t} \% \mathrm{C} 3 \% \mathrm{~A} 9$ rinaires+sans+Fronti $\% \mathrm{C} 3 \% \mathrm{~A} 8 \mathrm{res}+(\mathrm{AVSF}) \% 2 \mathrm{C}+\mathrm{CSE} \% 2 \mathrm{C}+\mathrm{Minist} \% \mathrm{C} 3 \% \mathrm{~A} 8 \mathrm{re}+$ $\mathrm{de}+1 \% 27 \% \mathrm{C} 3 \%$ A9levage+et+des+productions+animales+du+S\%C3\%A9n \%C3\%A9gal $\% 2 \mathrm{C}+2017 \&$ aqs $=$ chrome..69i57.621j0j4 \&sourceid=chrome\&ie=UTF-8 (accessed on 2 September 2020).

70. Thioune, A.A. Methodological Guide for the Implementation and Animation of Pastoral Units in Senegal. 2017. Available online: https:/ / www.avsf.org/fr/posts / 2202/full/guide-methodologique-de-mise-en-oeuvre-et-d-animation-des-unites-pastoralesau-senegal (accessed on 16 July 2021).

71. Ancey, V.; Wane, A.; Müller, A.; André, D.; Leclerc, G. Paying for water in the Ferlo Pastoral strategies for community water management. Autrepart 2008, 46, 51-66. [CrossRef]

72. Yagüe, J.L.; Montes, A.; Morales, F.J. Evaluation of Development Projects: A Process-Centered Approach in the Outskirts of Lima, Peru. Cuad. Desarro. Rural 2013, 10, 181-200.

73. Zabala, A.; Sullivan, C. Multilevel Assessment of a Large-Scale Programme for Poverty Alleviation and Wetland Conservation: Lessons from South Africa. J. Environ. Plan. Manag. 2017, 61, 1-22. [CrossRef]

74. Shin, W.; Kim, Y.; Sohn, H.-S. Do Different Implementing Partnerships Lead to Different Project Outcomes? Evidence from the World Bank Project-Level Evaluation Data. World Dev. 2017, 95, 268-284. [CrossRef]

75. Chu, J.; Garlock, T.M.; Sayon, P.; Asche, F.; Anderson, J.L. Impact Evaluation of a Fisheries Development Project. Mar. Policy 2017, 85, 141-149. [CrossRef]

76. Colombo, E.; Romeo, F.; Mattarolo, L.; Barbieri, J.; Morazzo, M. An Impact Evaluation Framework Based on Sustainable Livelihoods for Energy Development Projects: An Application to Ethiopia. Energy Res. Soc. Sci. 2018, 39, 78-92. [CrossRef]

77. Ka, A. Eating in Widou Thiengoly (North Senegal). From Remembered Abundance to Market Dependence. Ph.D. Thesis, Cheikh Anta DIOP University of Dakar, Dakar, Sénégal, 2016.

78. Demante, M.J. Support for the Capitalization of the Experience of the Pastoral Self-Promotion Project in the Ferlo; PAPF: Saint-Louis, Sénégal, 2006.

79. Manoli, C. The Herd and the Means of Securing Pastoral Camps A Study of Herd Management in the Rural Community of Tessekre, In the Senegalese Ferlo. Ph. D. Thesis, SupAgro, Montpellier, France, 2012.

80. Santoir, C. Sedentarization of nomads and pastoral hydraulics in Djolof (Senegal); ORSTOM: Paris, France, 1980; 72p.

81. Reboul, C. Danger d'oasis ? Aléas d'une Politique de Sédentarisation. Le Forage de Labgar Au Sénégal/Oasis, a Danger? Contingencies of a Sedentarization Policy: The Drilling Post of Labgar in Senegal. Civilisations 1978, 28, 120-139.

82. Rockström, J.; Steffen, W.; Noone, K.; Persson, Å.; Chapin, F.S.; Lambin, E.; Lenton, T.M.; Scheffer, M.; Folke, C.; Schellnhuber, H.J.; et al. Planetary Boundaries: Exploring the Safe Operating Space for Humanity. Ecol. Soc. 2009, 14, 1-33. [CrossRef]

83. Diouf, M. The crisis of adjustment. Polit. Afr. 1992, 3, 24.

84. United Nations Convention to Combat Desertification in Those Countries Experiencing Serious Drought and/or Desertification, Particularly in Africa. 1994. Available online: http://portails.cilss.bf/IMG/pdf/parsdocument.pdf (accessed on 16 July 2021).

85. Wane, A.; Ancey, V.; Grosdidier, B. Pastoral units in the Senegalese Sahel, management tools for livestock and pastoral areas. Sustainable project or sustainable development project? Dév. Durable Territ. Économie Géographie Polit. Droit Sociol. 2006. [CrossRef]

86. Sané, Y. Decentralization in Senegal, or how to reform to better maintain the status quo. Cybergeo Eur. J. Geogr. 2016. [CrossRef]

87. DECREE $N^{\circ}$ 2002-166 Fixing the Territorial Jurisdiction and the Chief Town of the Regions and Departments. 2002. Available online: http:/ / www.jo.gouv.sn/spip.php?article1867 (accessed on 16 July 2021).

88. High Level Political Forum (HLPF). Sustainable Development Goals (SDGs). Dakar, Senegal. 2018. Available online: https: / / sustainabledevelopment.un.org/content/documents/19253Rapport_national_volontaire_Snegal_versionn_finale_ juin_2018_FPHN2.pdf (accessed on 17 July 2021).

89. National Ecovillage Agency (NEA); AGIR. Ecovillages: For Sustainable and Humane Development, Good Resilience Practice. 2018. Available online: https://www.food-security.net/wp-content/uploads/2018/11/SENEGAL-BPR_01_FR.pdf (accessed on 17 July 2021).

90. 90. Republic of Senegal, PSE. Emerging Senegal Plan. 2014. Available online: https://www.sec.gouv.sn/sites/default/files/ Plan\%20Senegal\%20Emergent_0.pdf (accessed on 17 July 2021).

91. APIX. Senegal, Land of Investment, Senegal Emergent; Dakar, Senegal; 2018. Available online: https://investinsenegal.com/wpcontent/uploads/2018/10/APIX_Fiche-Fran\%C3\%A7ais-2018_lite.pdf (accessed on 17 July 2021).

92. UNCCD. The Great Green Wall Implementation Status and Way Ahead to 2030, Advanced Version; 2020. Available online: https: / / catalogue.unccd.int/1551_GGW_Report_ENG_Final_040920.pdf (accessed on 17 July 2021).

93. Zinsstag, J.; Schelling, E.; Waltner-Toews, D.; Tanner, M. From “One Medicine” to “One Health" and Systemic Approaches to Health and Well-Being. Prev. Vet. Med. 2011, 101, 148-156. [CrossRef] [PubMed] 
94. Otto-Portner, H.; Scholes, B.; Agard, J.; Archer, E.; Bai, X.; Barnes, D.; Burrows, M.; Chan, L.; Cheung, W.L.; Diamond, S.; et al. IPBES-IPCC Co-Sponsored Workshop Report Synopsis on Biodiversity and Climate Change. 2021. Available online: https://ipbes.net/ sites/default/files/2021-06/20210609_workshop_report_embargo_3pm_CEST_10_june_0.pdf (accessed on 17 July 2021).

95. Laville, C. Military Expenditures and Development Assistance in the Sahel: What Balance. Ferdi Working Paper. 2016. Available online: https:/ / ferdi.fr/publications/les-depenses-militaires-et-l-aide-au-developpement-au-sahel-quel-equilibre (accessed on 16 July 2021).

96. Leclerc, G.; Sy, O. Spatialized indicators of pastoral transhumance in Ferlo. Cybergeo Eur. J. Geogr. 2011. [CrossRef]

97. Imperato, P.J. Problems in Providing Health Services to Desert Nomads in West Africa. Trop. Doct. 1975, 5, 116-123. [CrossRef]

98. Holechek, J.L.; Cibils, A.F.; Bengaly, K.; Kinyamario, J.I. Human Population Growth, African Pastoralism, and Rangelands: A Perspective. Rangel. Ecol. Manag. 2017, 70, 273-280. [CrossRef]

99. Ali, M.; Cordero, J.P.; Khan, F.; Folz, R. 'Leaving No One behind': A Scoping Review on the Provision of Sexual and Reproductive Health Care to Nomadic Populations. BMC Womens Health 2019, 19, 161. [CrossRef] [PubMed]

100. Steinfeld, H.; Gerber, P.; Wassenaar, T.; Castel, V.; Rosales, M.; de Haan, C. Livestock's Long Shadow; Food and Agriculture Organisation: Roma, Italy, 2006; 390p.

101. Glatzle, A. Questioning Key Conclusions of FAO Publications 'Livestock's Long Shadow' (2006) Appearing Again in 'Tackling Climate Change Through Livestock' (2013). Pastoralism 2014, 4, 1. [CrossRef]

102. Rasmussen, K.; Brandt, M.; Tong, X.; Hiernaux, P.; Diouf, A.A.; Assouma, M.H.; Tucker, C.J.; Fensholt, R. Does Grazing Cause Land Degradation? Evidence from the Sandy Ferlo in Northern Senegal. Land Degrad. Dev. 2018, 29, 4337-4347. [CrossRef]

103. Adriansen, H.K.; Nielsen, T.T. Going Where the Grass Is Greener: On the Study of Pastoral Mobility in Ferlo, Senegal. Hum. Ecol. 2002, 30, 215-226. [CrossRef]

104. Lade, S.J.; Walker, B.H.; Haider, L.J. Resilience as Pathway Diversity: Linking Systems, Individual and Temporal Perspectives on Resilience. arXiv 2019, arXiv:1911.02294. [CrossRef]

105. Perrotton, A.; Ka, A.; Goffner, D. Wayfinder and Collective Improvement of Resilience in the Department of Ranérou Ferlo. 2019. Available online: https://www.researchgate.net/publication/344812363_WAYFINDER_et_amelioration_collective_de_la_resilience_dans_ le_departement_de_Ranerou_Ferlo (accessed on 16 July 2021).

106. Deberre, J.-C. Decentralization and local development. Afr. Contemp. 2007, 221, 45-54.

107. Marie, J.; Idelman, E. Decentralization in West Africa: A revolution in local governance? EchoGéo 2010. [CrossRef]

108. Talitha, T.; Firman, T.; Hudalah, D. Welcoming Two Decades of Decentralization in Indonesia: A Regional Development Perspective. Territ. Polit. Gov. 2020, 8, 690-708. [CrossRef]

109. Sujarwoto, S. Why Decentralization Works and Does Not Works? A Systematic Literature Review. JPAS J. Public Adm. Stud. 2017, 2, 1-10. [CrossRef]

110. Canare, T. Decentralization and Development Outcomes: What Does the Empirical Literature Really Say? Hacienda Pública Esp. Rev. Public Econ. 2021, 237, 111-151.

111. Platteau, J.-P.; Abraham, A. Participatory Development in the Presence of Endogenous Community Imperfections. J. Dev. Stud. 2002, 39, 104-136. [CrossRef]

112. Nelson, N.; Wright, S. Power and Participatory Development: Theory and Practice; ITDG Publishing: Rugby, UK, 1995; ISBN 978-1-85339-241-2.

113. Bixler, R.P.; Dell'Angelo, J.; Mfune, O.; Roba, H. The political ecology of participatory conservation: Institutions and discourse. J. Polit. Ecol. 2015, 22. [CrossRef]

114. Galvin, M.; Haller, T. People, Protected Areas and Global Change: Participatory Conservation in Latin America, Africa, Asia and Europe; University of Zurich: Zurich, Switzerland, 2008; Volume 3.

115. Berkes, F. Community-Based Conservation in a Globalized World. Proc. Natl. Acad. Sci. USA 2007, 104, 15188-15193. [CrossRef]

116. Mubita, A.; Libati, M.; Mulonda, M. The Importance and Limitations of Participation in Development Projects and Programmes. Eur. Sci. J. ESJ 2017, 13, 238. [CrossRef]

117. Campbell, L.M.; Vainio-Mattila, A. Participatory Development and Community-Based Conservation: Opportunities Missed for Lessons Learned? Hum. Ecol. 2003, 31, 417-437. [CrossRef]

118. Barrett, C.B.; Constas, M.A. Toward a Theory of Resilience for International Development Applications. Proc. Natl. Acad. Sci. USA 2014, 111, 14625-14630. [CrossRef] [PubMed]

119. Kane, C.H.; Diene, M.; Fall, M.; Sarr, B.; Thiam, A. Reassessment of the Resources of a Deep Aquifer System under Physical and Chemical Constraints:The Maastrichtian Aquifer. J. Water Resour. Prot. 2012, 4, 217-223. [CrossRef]

120. Peiry, J.-L.; Voldoire, O. Climatic Framework and Water Resources in the Senegalese Great Green Wall Area. In The Great Green Wall, An African Response to Climate Change; CNRS Editions: Paris, France, 2019.

121. Biggs, R.; Schlüter, M.; Biggs, D.; Bohensky, E.L.; BurnSilver, S.; Cundill, G.; Dakos, V.; Daw, T.M.; Evans, L.S.; Kotschy, K.; et al. Toward Principles for Enhancing the Resilience of Ecosystem Services. Annu. Rev. Environ. Resour. 2012, 37, 421-448. [CrossRef]

122. Lomeña-Gelis, M. A Meta-Evaluation of Sustainable Land Management Initiatives in Senegal; Universitat Politècnica de Catalunya: Barcelona, Spain, 2015. 